\title{
Cultural Tourism Model for Chinese Tourists Based on the Bali-China Cultural Landscape
}

\author{
I Made Sendra and Yohanes Kristianto \\ Faculty of Tourism, Udayana University Bali Indonesia
}

\begin{abstract}
The research article on the Cultural Tourism Model for Chinese Tourists based on the Bali-China Cultural Landscape aims to examine the mass tourism model for Chinese tourists who are developing in Bali and develop a cultural tourism model for Chinese tourists based on the Balinese-Chinese cultural landscape. In particular, this study aims to develop a cultural tourism model for Chinese tourists based on the Balinese-Chinese cultural landscape. This study uses qualitative methods to obtain natural settings including tourism stakeholders, namely the local government, the tourism industry, and customary village people who have cultural heritage. Qualitative methods are also used to interpret the symbols of Chinese traditions, culture and history in Bali, which will be explained from the point of view of the function and meaning of cultural artifact symbols in the tourism space. The research locations chosen were Denpasar District (Chinatown City Tour), Gianyar Regency (Kang Ching Wei Dance in Bali marine park), and Bangli Regency (Ulun Danu Batur Temple).
\end{abstract}

KEY WORDS: CULTURAL TOURISM MODEL, CHINESE TOURISTS, BALI-CHINA CULTURAL LANDSCAPE.

\section{INTRODUCTION}

Bali Island is one of the popular tourist destinations for Chinese tourists. The number of Chinese tourist visits to Bali has also increased very rapidly. It is recorded that from 2013 to 2019 the number of Chinese tourist visits to Bali has increased by 19.3\% per year[1] (Central Bureau of The number of Chinese tourist arrivals still dominates, but if seen from the level of expenditure it only reaches an average of US \$965[2]. This low expenditure does not have a significant effect on the economy of Bali[3].

\section{ARTICLE INFORMATION}

Received 30th Oct 2020 Accepted after revision 13th Dec 2020 Print ISSN: 0974-6455 Online ISSN: 2321-4007 CODEN: BBRCBA

Thomson Reuters ISI Web of Science Clarivate Analytics USA and Crossref Indexed Journal

\section{Clarivate
Analytics}

NAAS Journal Score 2020 (4.31)

A Society of Science and Nature Publication,

Bhopal India 2020. All rights reserved.

Online Contents Available at: http//www.bbrc.in/

Doi: http://dx.doi.org/10.21786/bbrc/13.15/10
The low expenditure of Chinese tourists is due to the payment system with virtual money and the use of the WeChat and Ali Pay applications [4] In fact, Mandarin tour guides tend to use tourists as money machines to cover the zero dollar tour package subsidies sold by travel agents and tour operators to Chinese tourists[5] [6] Research results which show that Chinese tourists have a fairly low interest in cultural tourism. Of the 188 Chinese tourist respondents who visited Bali, only 5.4\% were interested in visiting historical and cultural destinations[7] Based on the urgency of the problem of Chinese tourists in Bali, this research needs to be done to get a special interest tourism model for Chinese tourists as a quality tourism model.

Literature Review And Hypotheses Development: Research on 104 Chinese tourists regarding tourism behavior. The results showed that Chinese tourists have an interest in shopping tourism in traditional souvenir centers on the recommendation of friends and relatives. This shows

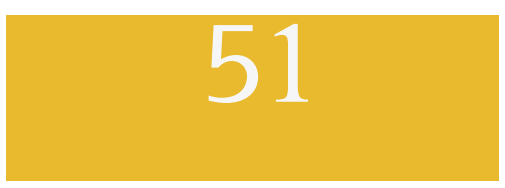


that local Balinese products still have the potential to be commodified as products that can be sold to Chinese tourists, given the interest of Chinese tourists to shop[8]. Chinese tourists have an interest in the following things. Of the 188 respondents, expressed their interest in the uniqueness of tradition (19.3\%), spa and aromatherapy (13.0\%), traditional arts (14.8\%), Balinese culinary (13.0\%), Balinese architecture (10.8\%), handicrafts (10.8\%), religious and spiritual activities (7.6\%), history and archeology (5.4\%), rural life (1.3\%).[9].

Based on the results of this study, cultural potential still has the opportunity to be developed as an alternative tourism for Chinese tourists related to the characteristics of Chinese tourists in Indonesia. This study found several characteristics of Chinese tourists in Indonesia. Most of them are between 25-44 years old and work as professionals, managers and employees. They like to come in groups with a stay period of about seven days. In addition, they chose star hotels as their top choice for accommodation. On average, they spent USD 1,018 during their visit to Indonesia. Most of them get information about Indonesian tourism and destinations from friends / family and social media. However, the number of Chinese tourists to Indonesia has more than doubled in the last four years. The high penetration of Chinese tourists occurs in Bali while massive growth is occurring in Manado[10]. Chinese tourists have a preference for visiting historical relics, such as Tanah Lot Temple, Penglipuran tourist village, Bedugul, Subak Tegalalang. Regarding culture, Chinese tourists also have a preference for watching Barong Dance, the Bali Arts Festival, and love the atmosphere of Nyepi, wearing traditional Balinese clothes for pre-wedding photos and liking traditional Balinese massage[11].

This also reinforces that cultural tourism has the potential to be developed as an alternative tourism for Chinese tourists. Motivation of Chinese tourists visiting Bali is to get benefits for their personal, social and organizational life related to hospitality, services and weather. The results of his research also found that Chinese tourists have the intention to visit again and the intention to recommend to their friends. This shows that Chinese tourists have the potential for loyalty to come back. This potential can be used as the basis for modeling alternative tourism for Chinese tourists[12]. Balinese people's perceptions of the behavior of Chinese tourists visiting Bali. The results showed that the Balinese people had doubts about the behavior of Chinese tourists related to sustainable tourism because people saw that Chinese tourists were practicing zero dollars and mass tourism activities that could damage the natural carrying capacity of Bali. This can be used as initial data in developing alternative tourism for Chinese tourists visiting Bali[13]. Regarding the potential of Balinese-Chinese culture as a basis for developing special interest tourism, research on traces of Balinese-Chinese culture. The identification results show that Bali-Chinese tangible and intagible culture has the potential to be developed as a special interest tourist destination for Chinese tourists[14].

\section{RESEARCH METHODOLOGY}

Research on the Cultural Tourism Model for Chinese Tourists based on the Balinese-Chinese Cultural Landscape uses qualitative methods to reveal the sociocultural meaning of a phenomenon[15] In line with the opinion of qualitative design takes a natural setting according to what is in the field[16]. For this reason, researchers are open and adapt to any phenomena that appear in the field during research. The phenomenon in this study is cultural tourism for Chinese tourists. Thus, this study focuses on Chinese tourists visiting Bali as research subjects. While the object of this research is the Balinese-Chinese cultural landscape.

\section{RESULTS AND DISCUSSION}

Historical Landscape (HL) and Cultural Landscape (CL) are the main resources for the development of cultural tourism. Tourism Landscape (TL) always manifests itself in a space containing natural, historical and cultural attractions [17]. The loss or extinction of the Historical Landscape and the Cultural Landscape which are in situ causes an inability to manage historical and cultural resources in a sustainable manner. This means that, if tourism management violates intrinsic and extrinsic values and characteristics of historical and cultural resources, not only will the area's attractiveness decrease, but also tourism itself will experience declination[18] In the end, the complexity of the relationship between the tourism landscape and the historical and cultural landscapes will lead to a point of tension between the poles of conservation and exploitation for economic interests (tourism function). The meeting between the Historical Landscape (HL), the Cultural Landscape (CL) and the Tourism Landscape (TL), can be described as the Landscape of the Regions of Origin of Tourists [19] and the Cultural Landscape of Bali[20].

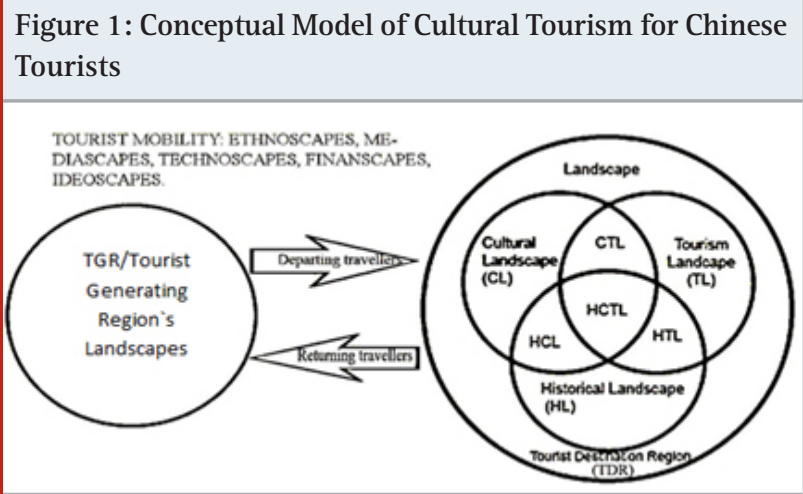

CONCLUSION

Historical and Cultural Tourism Landscape Model (HCTL) can be used as principles in developing special interest tourism models. Special interest tourism is a tour conducted by tourists from the area of origin of tourists who wish to develop a particular interest towards 
a tourist destination to visit sites or places related to certain subjects, such as Historical and Cultural Heritage Landscapes (HCTL).

Limitation and Study Forward: Further research needs to be done to make cultural tour packages for Chinese tourists by prioritizing the potentials owned in the china town area in Bali.

\section{ACKNOWLEDGEMENTS}

The author would like to thank the Institute for Research and Community Service, Udayana University which has provided research grants.

\section{REFERENCES}

2019. Statistics of Bali Province.

Appadurai, A. 1996. Modernity at Large. Cultural Dimensions of Globalization . Minneapolis: University of Minnesota Press. Perda Bali No.2 of 2012.

Bali. Jurnal IPTA Vol.6, No. 2, 2018 Fakultas Pariwisata Universitas Udayana Program Studi Industri Perjalanan Wisata Rosyidi , M.I. 2018. The Characteristics of Chinese Tourists in Indonesia and Its

Berg, B.L. dan Lune, H. 2011. Qualitative Research Methods for the Social Sciences (8th Edition) 8th Edition. Publisher: Pearson

Butler, R. W. 1980.The Concept of a Tourist Area Cycle of Evolution and Implications for Management. Publisher: The Canadian Geographer.

dan Turis Mahal, Namun Begini Jadinya http://bali. tribunnews.com/2018/10/26/polemik-wisatawan-Cinadi-bali-butuh-turis-murah-dan-turis-mahal-namunbegini-jadinya?page $=4$. Accessed on 17 Februari 2019 Pukul 20.04

Denzin, N.K Dan Lincoln, Y.S. 2011. The SAGE Handbook Of Qualitative Research Fourth Edition.Publisher: SAGE Publications

Hendriyani, I.G.A.D. 2018. Characteristics And Strategies To Improve Chinese
Kusniarti,Seri AA.2018. Polemik Wisatawan Cina di Bali : Butuh Turis Murah

Mrda, Ana, et al. 2014. The importance of the concept of tourism carrying capacity for spatial planning: previous research, development and methodological approaches/Znacaj koncepta turisticke nosivosti za prostorno planiranje: dosadasnja istrazivanja, razvoj koncepta i metodoloski pristupi. Prostor, vol. 22, no. 2, 2014, p. 212. Accessed 7 Dec. 2020.

Outbound Tourist Travel To Indonesia. JBHOST, Vol 04 Issue 2, 2018: 169-178 Issn 2527-9092.

Performance in 2013-2017. Binus Business Review, 9(2), July 2018, 145-152 DOI: 10.21512/bbr.v9i2.4240 Wardani, A.A dan Suryanatha, A.A.P. 2014. Proceedings of the Sth Intenrational

Performance in 2013-2017. Binus Business Review, 9(2), July 2018, 145-152 D0I: 10.21512/bbr.v9i2.4240

Rosyidi , M.I. 2018. The Characteristics of Chinese Tourists in Indonesia and Its

Sendra, dkk. 2018. One Belt and One Road: The Cultural Diplomatic Relationship Between China and Bali From Historic Perspective dalam Southeast Asian Hakka Culture and One Belt and One Road International Youth Academic Forum. Fujian: Sanming University.

Sendra, dkk. 2018. Studi Motivasi, Kepuasan, dan Niat Berperilaku Wisatawan Asia ke Bali: Studi Komparasi Wisatawan China dan Jepang. Laporan Penelitian Dasar Unggulan Perguruan Tinggi. Denpasar: Universitas Udayana.

Sugianto, Sigit. 2018. Preferensi Wisatawan China Terhadap Cultural Tourism di

Tourism Studies Association Conference Tourism, Cities and the Environwent in the Asian Century. Wednesday 26th to Friday 28th November 2014 Department of Parks and Wildlife Perth, Western Australia.

Wisnawa, dkk. 2019. Persepsi Masyarakat Terhadap Perilaku Wisatawan Cina Terhadap Keberlanjutan Pariwisata Bali Dengan Pendekatan Sapta Pesona. E-journal Undhira. Accessed on 19 Februari 2019. 